\title{
Assessment of Ecosystem Services and Disservices in Urban Environment Using Multispectral Image Analysis and Geospatial Mapping
}

\author{
Md. Nazmul Haque*1, Irtija Alam², and Atif Aninda Rahman ${ }^{3}$ \\ Department of Urban and Regional Planning, Khulna University of Engineering \& Technology, Khulna-9203, Bangladesh \\ emails: ${ }^{* 1}$ nhaque13@urp.kuet.ac.bd; 2alam1617012@stud.kuet.ac.bd; and ${ }^{3}$ rahman1617020@stud.kuet.ac.bd
}

\section{ART ICLE INFO}

\section{Article History:}

Received: $13^{\text {th }}$ Decemberr 2020

Revised: 25th May 2021

Accepted: 29th May 2021

Published: 27th June 2021

\section{Keywords:}

Urban Environment

Ecosystem Services

Ecosystem Disservices

Image Analysis

ArcGIS

\begin{abstract}
A B S T R A C T
Ecosystem service and disservice components have a great impact on the environment as well as on urban life. The aim of the research is to assess the impact of ecosystem services and disservices by tracking the change over a span of 15 years (2005-2020) using satellite image analysis. It was conducted in wards 23 and 29 of Khulna City Corporation (KCC), an area adjacent to the river. The overall work breakdown has been rounded up in a methodological framework which cleaved into two parts focusing on ecosystem services, disservices and multispectral image analysis steps. Multispectral image analysis has been done using Normalized Difference Vegetation Index (NDVI) and Normalized Difference Build-up Index (NDBI). On the other hand, geospatial analysis has been done using Digital Elevation Model (DEM), Service Area Analysis (SAV) and other mapping tool including Geographic Information System (GIS) to show the changed impact of both ecosystem components. The study areas attain provisioning, habitat, cultural and regulatory service components and the disservice elements have been sorted out according to sources. Comparative study showed increase in the buildup area; vegetation coverage because of increasing vegetation, cultivation and gardening practices; good weather and water circulation condition and water body conservation which has significant positive impact on the area. The disservice component like poor drainage condition and solid waste management system and risky infrastructures have negative impact, need to address for the betterment of residence and environment.
\end{abstract}

\section{INTRODUCTION}

The trend of the fastest growing urbanization and internationalization creating a vast impact on the environment. Some of the impacts are increased population, developing industries with poor technologies, lack of proper provisioning and strong executing authority, unawareness is the reason for the environmental deterioration. This rapid urbanization has put compelling pressure on the urban ecosystem by biodiversity breakdown, habitat loss and environmental pollution (Tian et al., 2020). Urban ecosystem glues a city and helps in building up a sound life with proper health, security and other core features of livelihood of the citizens (Bolund \& Hunhammar, 1999; European Environment Agency, 2011; Odum, 1989; Tzoulas et al., 2007). Also, it poses a negative effect on biodiversity and ecosystem and human well-being as well (Chabay, 2018). The urban ecosystem services usually refer to the opportunities provided by the urban ecosystem and its components (Andersson et al., 2007; Gómez-Baggethun \& Barton, 2013). Again ecosystem service is a heavy concept that presents the contribution of an ecosystem to human well-being (Isbell et al., 2017). On the other hand ecosystem, disservice can be defined as feature, mechanism and properties of an environment which have created a perceived or actual detrimental effect on human well-being (Shackleton et al., 2016).

Ecosystem-based researches are mainly focused on goods and services to identify the beneficial value to the ecosystem and humans as well (de Groot et al., 2010). When the output of the ecosystem for humans and the environment are positive it is termed as "ecosystem 
services" the component incorporates for service termed as "ecosystem service components". On the other hand, if the outputs are harmful the same ecosystem and incorporating components termed as "ecosystem disservice" and "Ecosystem disservice component" respectively (Rasmussen et al., 2017; Schaubroeck, 2017). The ecosystem and wellbeing are closely linked (Rasmussen $e t$ al., 2017). The Colombian Caribbean region is one of the most biodiverse regions in the world helping human wellbeing providing essential ecosystem services at the local, national and global levels (Aldana-Domínguez et al., 2017; Le Saout et al., 2013). Besides the study on ecosystem services, the study on ecosystem disservices is also very important to achieve sustainability and improvement of urban life in a systematic way. Identifying the relationship between and ecosystem services and disservices and addressing the root causes of disservices may enhance environmental management and ecological protection (Sun et al., 2020). For economic disservice, a study had done in the marine ecosystem in the Polish Baltic sea defining disservices to be sea level rise, sea floods, erosion, toxic bloom, eutrophication, pollution etc. (Lyytimäki et al., 2008). Another study has been done in northwest of Beijing to identify the environmental problems based on ecosystem disserve bundles for better environment management measures (Sun et al., 2020).

There are many studies on ecosystem services all over the world. Hanna et al., 2018 studied riverine ecosystem service to suggest effective measure to protect and manage the riverine ecosystem service bundles; Smart et al., 2011 applied the ecosystem service concept to manage air quality in UK, Maskell et al., 2013 studied the ecosystem services in Great Britain to explore the ecosystem constaints to service delivery and biodiversity. According to (Rendón et al., 2019) a linkage was buildup between the services and disservices of the existing area using a methodological framework. In Bangladesh, Islam et al., studied to identify the natural and anthropogenic drivers of change that affect the ecosystem services of the Sundarbans Mangrove regions in Khulna, Satkhira and Bagerhat districts of Khulna Division based on secondary data and field interview (Islam et al., 2018); Sarker et al. also studied on the ecosystem of Sundarbans to identify the variables which drive the mangrove biodiversity (Sarker $e t$ al., 2019. Another study is done by Alam and Mohammad on applied ecosystem approach of regulation, monitoring, and management of Sundarbans as suitable means of conservation and sustainable development (Alam \& Mohammad, 2018). In Khulna city-related studies regarding environmental profiling (Rabbi et al., 2021) and environmental risk zone identification (Haque et al., 2020) have been done. Works have been done on mapping out blue ecosystem services in the wards of Khulna city (Haque et al., 2019) but further study on the disservices and services on land has not been yet done on Khulna city.

This research fills the gap in several ways. The spatiotemporal change from 2005 to 2020 based on ecosystem service and disservice components and its impacts on urban life are analyzed. Spatial analysis like DEM and two indices named NDVI and NDBI using multispectral image analysis for both service and disservice components are performed here. For disservice elements identification, location-based GIS mapping was done to sort out components like open dustbins, lack of tube wells, clogged or untreated drains, and risky buildings of the area. The study also relates the services and disservices of the area using proper reasoning of the framework. These changes and figures have helped to come to a conclusion about the service and disservice elements and assess them accordingly. But the study was not free from limitations. Due to a smaller study area and limited time period, the change was not that significant . Besides the quality analysis of waterbody, existing atmosphere analysis of dust particles was not possible due to limited time and the emergence of the COVID-19 outbreak.

The principal objective of the study was to make profile of ecosystem service and disservice components of the study area. Emphasis has been given on the comparison of vegetation, build environment coverage. It was done by the NDVI and NDBI respectively. A time extent from year 2005 to 2020 was taken for the study. Here environmental service indicators were taken as ecosystem service components. It was done to assess the environmental condition by justifying their role.

\section{STUDY AREA}

The selected study area is ward no. 23 and 29, the two adjacent areas of Khulna City Corporation. The area fall in the the ancient part of Khulna city near the Rupsha River. These two wards of the KCC have been explored based on secondary data, google earth and google map and found that they attained more ecosystem components than other wards in terms of: 1. Provisions like edible plants, water supply, fiber and fuel and raw material and ornament and medicine resources; 2. Regulating like air Quality, Climate condition, water regulation etc. 3. Habitat or Supporting like Nursery and 4. Cultural and Amenity like recreational activity, cultural heritage, spiritual and religious inspiration. A reconnaissance survey was conducted in the wards. It was found that those these wards attain a rich amount of ecosystem service and disservice components compared to other wards of the KCC boundary. Furthermore, this study has focused on the core unit (ward) of the urban area. There are some disservice components like poor drainage construction and sewerage system, no proper solid waste management system, degradation of blue ecosystem components like water body, lack of dustbin, and risky and old infrastructures. But authorities' concern is not sufficient to solve these problems. Finally, as the area consented to the study aim appropriately, it was selected as study area. The boundary road of the area is Khan-Jahan-Ali Road, South Central Road, Upper Jashore Road and Rupsha Stand Road. The total number of households of ward 23 is 3226 and total population is 13793. The total number of households of ward 29 is 4230 and total population is 17763 . The population density of the total study area is 1030 sq. km under the Khulna Sadar Thana. Ward 29 is predominately a residential area but ward 23 is a commercial area. The road network and circulation, and adequacy of utility services condition are 
comparatively good but the condition of the drainage and water service are not in good condition. In the candidate study area, the earliest settlements of the Khulna were developed and many buildings are having the sign of ancient heritage. There is a Missionary Community in the area and contributes to enriching the bio-diversity of the area by means of cultivation, gardening, conservation of water bodies and ornamentation.

\section{RESEARCH METHODOLOGY}

Figure 1 showns the location of ward 23 and 29 in KCC boundary.

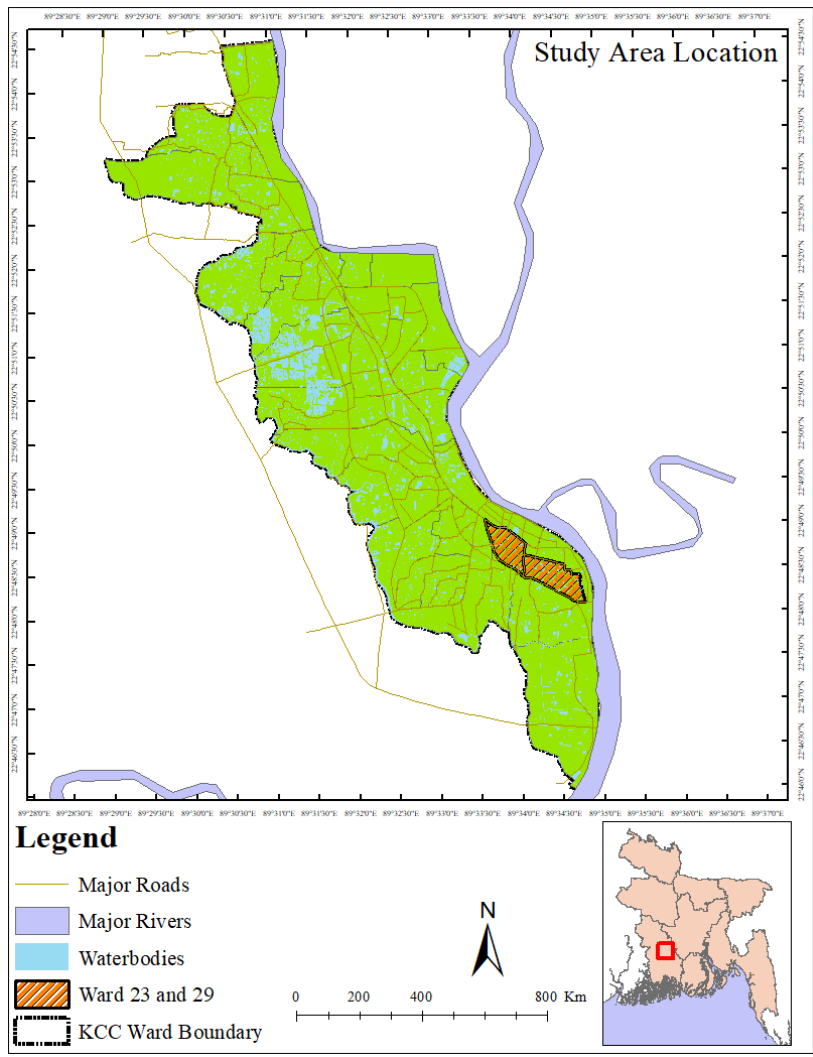

Figure 1: Location of ward 23 and 29 in KCC boundary

\section{A. Survey Design}

Firstly, a reconnaissance survey was conducted to know the overall environmental context and other features of the study area associated with ecosystem and environment. Data has been collected by questionnaire and checklist, prepared based on the available service and disservice components and the overall environmental condition of the study area from the observation of previous reconnaissance surveys. Among the bundle of service and disservice components, the accessible and available data were taken. The service components are water body, water supply point, agricultural land, greeneries, erosion protection, water regulation, cultural heritage and identity in the sense of place, design and belongings, spiritual and religious value, services comments, educational and scientific opportunities for formal and informal education and training (de Groot et al., 2010) and the disservice components are waste dumping in the open places, risk of collapse and debris structures, sediment export on the water body (Sun et al., 2020), poor drainage system, dust particles in the air. The survey based on the questionnaire was conducted in households and the checklist survey was conducted in both study areas and administration offices. Analysis was done based on the collected data. "Separation and Impact Analysis Methods" have been used where separation and discussion based on the impact of the elements were done. The desk analysis was based on a series of methods applied on the data retrieved from the field data collection. The obtained information was properly presented using mapping techniques in GIS. Further secondary data were collected from the USGS website for in-depth analysis of the study area for showing the temporal change.

\section{B. Technical Works for Presenting the Existing Scenario}

The service range of the dustbins which were only three in number was determined by creating a buffer of about $100 \mathrm{~m}$ which was taken from the case study of Coimbatore India. The buffer tool of ArcGIS was used for this process. For determining the elevation of the areas, a tool known as the Training Center XML(TCX) converter was used and from google earth the latitude, longitude and altitude data were extracted and inserted in the TCX converter. Then processing the Inverse Distance Weighted (IDW), interpolation tool for Digital Elevation Model, in the ward boundary the elevation map of the area was determined. Waterbody depth data were collected in the field survey and Inverse Distance Weighted was also applied to determine the overall groundwater table in the area. Coordinates observed from field survey identified in google earth tool and converted the ".kml" file from there into shapefile points in GIS to locate open waste dumping point, tube well location, existing service facilities, deteriorated water bodies and risky infrastructures in the study area. Mainly these tools have helped to bring the study area in a precise and presentable manner.

\section{Methods Used in Spatiotemporal Indexing}

For a better understanding of the change in the study area environment temporal change was observed using satellite images extracted from the U.S. Geological Survey (USGS) website and the process followed is portrayed below:

\section{i. Data Collection and Preparation}

For image analysis LANDSAT images from 2005 and 2020 were taken from USGS (United State Geological Survey) website. The temporal gap was taken to observe the change in buildup area, vegetation and water bodies in the survey region. A primary survey was conducted to locate the places of prominent features of the area. The two LANDSAT images were Landsat 5 TM for 2005 and Landsat 8 OLI for 2020. The change of ecosystem components selected for the study and its impact are not evidencede in a short period. For this, an extent of 15 years time span has provided the research to explicate a significant change in ecosystem components and its impact on the area. The different electromagnetic radiations or the bands produced from these two satellites were used for determining processes such as Natural Difference Vegetative Index (NDVI), Natural Difference Water Index (NDWI) and Natural Difference Built-up Index (NDBI) defined in Table 1. The survey area a clear sky and free 
from clouds during the early parts of month May during which the image from 2005 was taken and from the later parts of September from which the image from 2020 was taken. Both were free from cloud covers, then again while obtaining the data cloud covers have been taken to be less than $10 \%$ downloading from USGS. For both images, the path was 138 and the row was 44 with an image resolution of $30 \mathrm{~m}$.

Table 1

Showing the different band numbers and their attributes of the Landsat image indices

\begin{tabular}{ccccc}
\hline \hline \multirow{2}{*}{ Indices } & \multicolumn{2}{c}{ LANDSAT 8, OLI } & \multicolumn{2}{c}{ LANDSAT 5, TM } \\
\cline { 2 - 5 } & $\begin{array}{c}\text { Band } \\
\text { number }\end{array}$ & $\begin{array}{c}\text { Band } \\
\text { attribute }\end{array}$ & $\begin{array}{c}\text { Band } \\
\text { number }\end{array}$ & $\begin{array}{c}\text { Band } \\
\text { attribute }\end{array}$ \\
\hline NDVI & 4 and 5 & $\begin{array}{c}\text { Visible red } \\
\text { and NIR }\end{array}$ & 3 and 4 & $\begin{array}{c}\text { Visible red } \\
\text { and NIR }\end{array}$ \\
NDBI & 5 and 6 & $\begin{array}{c}\text { NIR and } \\
\text { SWIR }\end{array}$ & 4 and 5 & $\begin{array}{c}\text { NIR and } \\
\text { SWIR }\end{array}$ \\
\hline \hline
\end{tabular}

\section{ii. Multi-Spectral Image Dataset}

The two sets of images taken here for modifications are from 2005 and 2020 which had the sensors TM (Thematic Mapper) and OLI (Operational Land Imager) respectively. The spectral resolution for both was $30 \mathrm{~m}$. To detect the change in vegetation and buildup area of the location, images from 13/04/2005 of LANDSAT 5 TM and $16 / 11 / 2020$ of LANDSAT 8 OLI. Superior weather condition affects its transmission and scrambling (Sannier et al., 2014). For this reason, data were taken from the weather condition which would give clear and accurate visuals and the least cloud cover. One of the affecting factors of sun azimuth and elevation are the differences that happen diurnally and seasonally (Singh, 1989). That is why which season to give the best results and the best time of the day was also taken into consideration. Table 2 presents the Multi-spectral image data description, of the two images used landsat-5 Thematic Mapper (TM) and landsat-8 Operation Land Imager (OLI).

Table 2

Multi-spectral image data description, of the two images used landsat-5 Thematic Mapper (TM) and landsat-8 Operation Land Imager (OLI)

\begin{tabular}{cccccc}
\hline \hline Satellite & Sensor & Path/Row & DoY & $\begin{array}{c}\text { Resolution } \\
\text { (m) }\end{array}$ & $\begin{array}{c}\text { Cloud cover } \\
\text { (\%) }\end{array}$ \\
\hline $\begin{array}{c}\text { Landsat-5 } \\
(13 \mathrm{Apr} . \\
2005)\end{array}$ & TM & $138 / 44$ & 120 & 30 & 10 \\
$\begin{array}{c}\text { Landsat-8 } \\
(16 \text { Nov. } \\
2020)\end{array}$ & OLI & $138 / 44$ & 321 & 30 & 10 \\
\hline \hline
\end{tabular}

\section{iii. Calculation of Normalized Difference Vegetation Index (NDVI)}

NDVI shows the position of the good vegetation of the intended area. The darkest area is the greenest area and the brightest is the least green. For NDVI calculation two bands red and near-infrared radiation bands are used in the main equation. Here, the red band absorbs the most radiation and the near-infrared band radiates the most. The band no. 3 and 4 define red and near-infrared in Landsat- 5 and for Landsat- 8 it is band 4 and band 5 .

$N D V I=\frac{\text { NIR-visible Red }}{\text { NIR+visible Red }}$

It varies from -1 to $+1,-1$ refers to the least number of vegetation and +1 the best vegetation present in the area.

\section{iv. Calculation of Normalized Difference Build- Up Index (NDBI)}

NDBI shows the condition of the buildup area of the region. The brightest area has least building conditions and the darkest area has dense buildings. For NDBI also two bands are used namely the short-wave infrared band and the near-infrared band. TheLandsat 5 calculation requires band 5 and 4 and for Landsat- 8 it is band 6 and band 5 .

$N D B I=\frac{S W I R-N I R}{S W I R+N I R}$

The value of NDBI also ranges from -1 to +1 where +1 refers to the dense buildup area and -1 refers to the least density of area having buildings.

The land use distribution for NDVI from lowest to highest was a buildup area, paved road, grassland, shrubs and dense vegetation. And that for NDBI from lowest to highest is good vegetation, shrubs, bare land, metaled surface and buildup area. The lower limit and the higher limit of the NDVI and NDBI value were not the same but it needs to be normalized the value for corresponding category selection. For this, the value of the lower limit and the higher was calculated by averaging the all-lower limits and the higher limit respectively. Table 3 presents the Land use distribution, value range and category for NDVI and NDBI indices

Table 3

Land use distribution, value range and category for NDVI and NDBI indices (Haque et al., 2020)

\begin{tabular}{|c|c|c|c|c|c|}
\hline $\begin{array}{l}\text { NDVI } \\
\text { Value } \\
\text { Range }\end{array}$ & Category & Land Use & $\begin{array}{c}\text { NDBI } \\
\text { Value } \\
\text { Range }\end{array}$ & Category & Land Use \\
\hline $\begin{array}{c}0.004 \\
- \\
0.072\end{array}$ & Very Low & $\begin{array}{l}\text { Build up } \\
\text { Area }\end{array}$ & $\begin{array}{c}-0.183 \\
- \\
-0.067\end{array}$ & Very Low & $\begin{array}{c}\text { Good } \\
\text { vegetation }\end{array}$ \\
\hline $\begin{array}{c}0.072 \\
- \\
0.118\end{array}$ & Low & $\begin{array}{l}\text { Paved } \\
\text { Road }\end{array}$ & $\begin{array}{c}-0.067 \\
- \\
-0.001\end{array}$ & Low & Shrubs \\
\hline $\begin{array}{c}0.118 \\
- \\
0.167\end{array}$ & Moderate & Grass Land & $\begin{array}{c}-0.001 \\
- \\
0.047\end{array}$ & Moderate & Bare Land \\
\hline $\begin{array}{c}0.167 \\
- \\
0.227\end{array}$ & Medium & Shrubs & $\begin{array}{c}0.047 \\
- \\
0.088\end{array}$ & Medium & $\begin{array}{l}\text { Metaled } \\
\text { Surface }\end{array}$ \\
\hline $\begin{array}{c}0.227 \\
- \\
0.360\end{array}$ & High & $\begin{array}{c}\text { Dense } \\
\text { Vegetation }\end{array}$ & $\begin{array}{c}0.088 \\
- \\
0.268\end{array}$ & High & $\begin{array}{c}\text { Build up } \\
\text { Area }\end{array}$ \\
\hline
\end{tabular}


Here, the change in value has been categorized from very low to high, where the lowest value defines the lowest amount of the calculated index and the highest value defines the highest amount of that calculated index. For vegetation, it showed $0.227-0.36$ which was categorized as high. The same went for NDBI where the highest and dense buildup area had the highest range of NDBI value. Here it was $0.088-0.268$, for the dense buildup area the value range was $-0.183--0.067$. The land use was from good vegetation. The overall research was mainly divided into two parts, fieldwork and desk work. Fieldwork comprised the findings of the region profile and desk work was built around imagery analysis and presenting them using mapping techniques of ArcGIS.

Methodological framework of the overall research is presented in Fig. 2. NDVI it showed $-0.004-0.072$ for the metaled road so it was categorized as very low vegetation there.

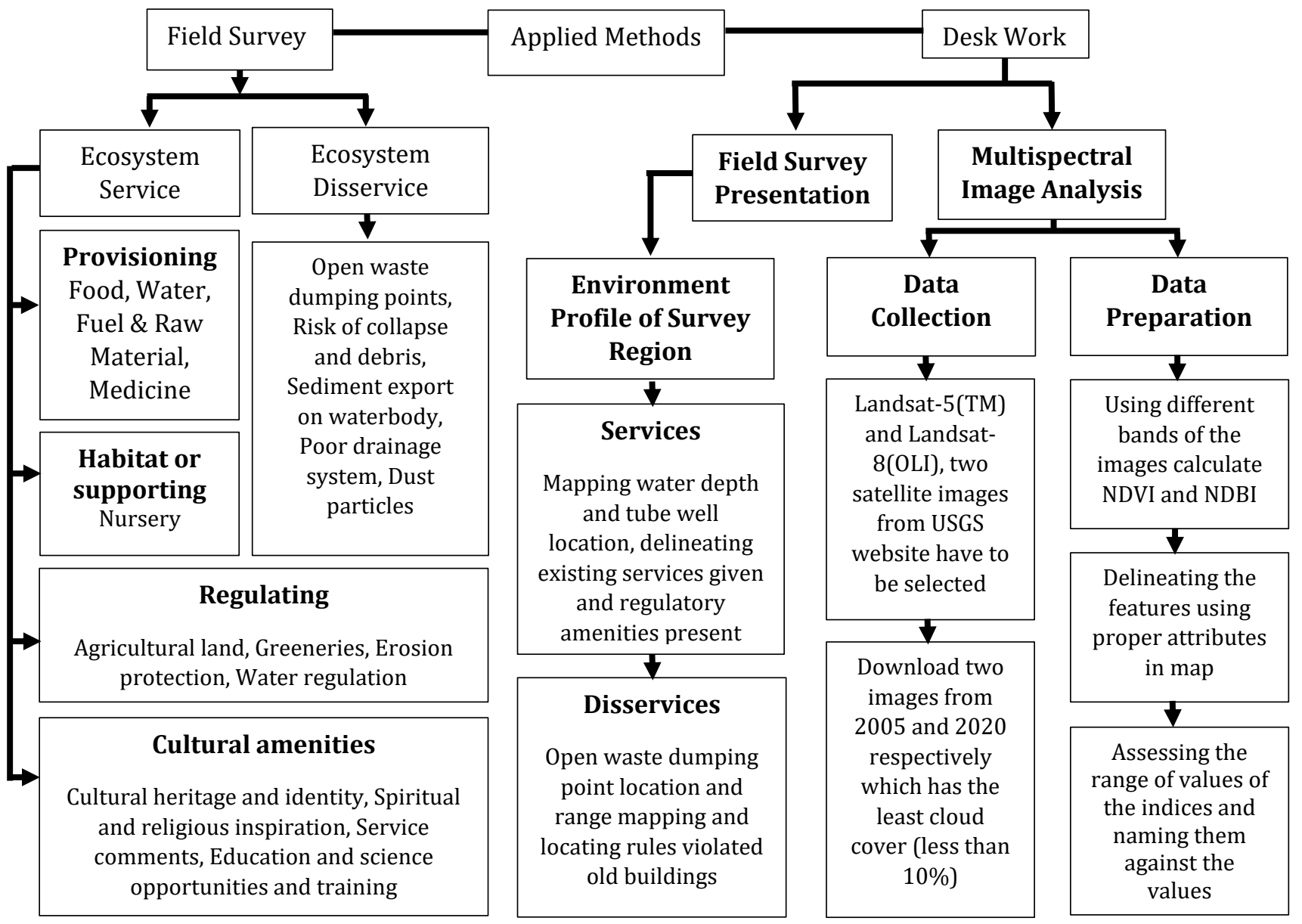

Figure 2: Methodological framework of the overall research

\section{RESULT AND DISCUSSION}

\section{A. Temporal Change in Climatic Elements}

The cloud coverage is positively correlated with humidity, rainfall determined by Random Effect Model (Rokonuzzaman \& Rahman, 2017) but in the study area there is a negative impact on humidity as well as sunshine, and temperature is quite uncertain. Data of 2009 were taken because no compact data of 2005 was available for Khulna city. The data was collected from secondary source where meteorological data of every month from 2009 to 2020 are recorded. For ease of presentation and analysis it the twelve months have been categorized into major 4 seasons summer, monsoon, autumn and winter, and explained the findings as well. In 2020, the average precipitations between April to June and July to September are $226 \mathrm{~mm}$ and $589 \mathrm{~mm}$, respectively which is recorded highest amount of rainfall since 2009 though there was no significant difference between the rainy day showed in Table 4. This record amount of rainfall and high visibility range for the year 2020 is correlated with cloud coverage, evaporation and declination of various kinds of pollutants for closing the industries all over the world in this pandemic situation for COVID-19. Table 4 also shows the humidity, sunny hour and sunny days which has a negative correlation with clouds coverage, precipitation, visibility range and wind speed in the year 2020 compared to 2009. Maximum and average wind speed shows a parallel relation but the trend breaks in 2019 and continued to 2020 for cyclone Foni (2019), super cyclone Amphan (2020), a heavy thunderstorm occurred in both years. 
Table 4

Yearly change in the meteorological attributes

\begin{tabular}{|c|c|c|c|c|c|c|c|c|}
\hline \multirow{2}{*}{$\begin{array}{l}\text { Components } \\
\text { Year }\end{array}$} & \multicolumn{2}{|c|}{ Jan-Mar } & \multicolumn{2}{|c|}{ Apr-Jun } & \multicolumn{2}{|c|}{ Jul-Sept } & \multicolumn{2}{|c|}{ Oct-Dec } \\
\hline & 09 & 20 & 09 & 20 & 09 & 20 & 09 & 20 \\
\hline $\begin{array}{l}\text { Max. Avg. } \\
\text { Temp }\left({ }^{\circ} \mathrm{c}\right)\end{array}$ & 32 & 31 & 36 & 36 & 31 & 32 & 28 & 30 \\
\hline $\begin{array}{l}\text { Min. Avg. } \\
\text { Temp }\left({ }^{\circ} \mathrm{C}\right)\end{array}$ & 18 & 19 & 27 & 26 & 26 & 27 & 19 & 21 \\
\hline $\begin{array}{l}\text { Avg. } \\
\text { Precipitation } \\
\text { (mm) }\end{array}$ & 3 & 27 & 70 & 226 & 200 & 589 & 40 & 322 \\
\hline $\begin{array}{l}\text { Rain Days } \\
\text { (No.) }\end{array}$ & 6 & 17 & 50 & 69 & 91 & 91 & 20 & 30 \\
\hline $\begin{array}{l}\text { Avg. Wind } \\
\text { Speed } \\
\text { (km/hr.) }\end{array}$ & 8.3 & 8.6 & 11.5 & 14.87 & 9.4 & 14.7 & 7.1 & 8.3 \\
\hline $\begin{array}{l}\text { Max. Wind } \\
\text { Speed } \\
(\mathrm{km} / \mathrm{hr} \text {.) }\end{array}$ & 8.3 & 14.2 & 11.5 & 22.4 & 9.4 & 20.7 & 7.1 & 12.4 \\
\hline $\begin{array}{l}\text { Visibility } \\
(\mathrm{km})\end{array}$ & 9.8 & 9.8 & 9.6 & 9.3 & 7 & 8.7 & 9.2 & 9.6 \\
\hline Cloud (\%) & 6 & 15 & 23 & 46 & 55 & 67 & 14 & 32 \\
\hline $\begin{array}{l}\text { Humidity } \\
(\%)\end{array}$ & 145 & 148 & 206 & 202 & 271 & 236 & 222 & 146 \\
\hline $\begin{array}{l}\text { Sunny Days } \\
\text { (No.) }\end{array}$ & 81 & 74 & 30 & 22 & 1 & 1 & 69 & 31 \\
\hline $\begin{array}{l}\text { Sunny Hr. } \\
\text { (hr.) }\end{array}$ & 258 & 282 & 352 & 206 & 214 & 143 & 226 & 191 \\
\hline
\end{tabular}

\section{B. Ecosystem Service Components}

The more diversity in vegetation indicates the more enriched ecosystem and this rich ecosystem serves us a healthier environment in urban areas where life is stagnant in between the buildup areas, pollutions and so on. The NDVI and NDBI analysis represent a comparison from the year 2005 to 2020 , it evident that the vegetation and building area playing an important role as ecosystem service components which is further described by image analysis in the next subsection.

\section{i. Temporal Change in Vegetation Coverage}

The comparative changes in vegetation type from the year 2005 to 2020 of KCC wards 23 and 29 are shown in Figure 3 . From Table 5 ward 23 shrubs type vegetation increases by $225 \mathrm{~km}^{2}$ and others decreased for predominately rooftop gardening and ground gardening. Table 5 also shows grass and dense vegetation land transformed into the buildings (mainly residential area) and the roof of the maximum buildings are adorned with different shrub type vegetation (filed observation). Inward 29 grassland, shrubs and dense vegetation increased by 1260,1728 and $819 \mathrm{~km}^{2}$ respectively from the year 2005 to 2020 . This increased amount of vegetation indicates the area holding a rich ecosystem developed over time and that is resulted for mainly 3 reasons observed in filed survey, 1) The people of the Christian Missionary planting more shrubs, grass, dense vegetation like mango tree garden for beautification, eating, medicine, shade and other service purposes; 2) vegetation (grass, shrub and dense vegetation) growing on the surface of water body and edges more than before; 3 ) Rooftop gardening and road side plantation. As the band uses to develop NDVI mainly used for identification of vegetation, for rooftop gardening, road side planation and plants on the edge and surface of water body all seems as vegetation land rather than water body or build or paved area and for this the result from Table 6 shows significant amount of decrease in build area but the scenario is not real for both wards.

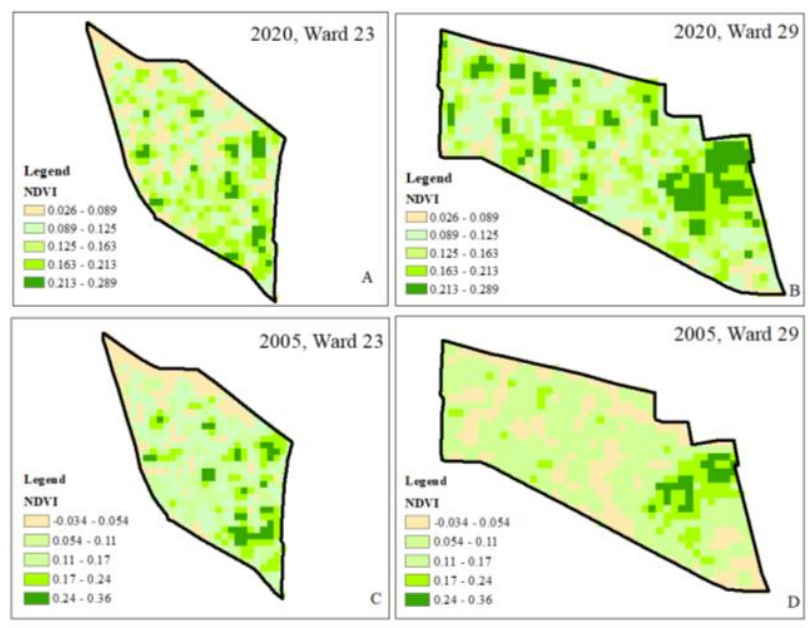

Figure 3: Normalized Difference Vegetation Index, (A) 2020, ward 23; (B) 2020, ward 29; (C) 2005, ward 23; and

(D) 2005, ward 29

Table 5

Change in Vegetation Coverage from the Year 2005 to 2020

\begin{tabular}{cccccc}
\hline \hline \multirow{2}{*}{$\begin{array}{c}\text { NDVI Value } \\
\text { Range }\end{array}$} & Land Use & \multicolumn{2}{c}{$\begin{array}{c}\text { Area }\left(\mathbf{k m}^{2}\right) \\
\text { Ward 23 }\end{array}$} & \multicolumn{2}{c}{$\begin{array}{c}\text { Area }\left(\mathbf{k m}^{2}\right) \\
\text { Ward 29 }\end{array}$} \\
\cline { 3 - 6 } & & $\mathbf{2 0 0 5}$ & $\mathbf{2 0 2 0}$ & $\mathbf{2 0 0 5}$ & $\mathbf{2 0 2 0}$ \\
\hline$-0.04-0.09$ & $\begin{array}{c}\text { Build-up } \\
\text { Area }\end{array}$ & 1044 & 1152 & 1764 & 180 \\
$0.09-0.13$ & Paver Road & 1602 & 1512 & 2952 & 729 \\
\hline $0.13-0.17$ & Grass Land & 1494 & 1269 & 1197 & 2457 \\
$0.17-0.24$ & Shrubs & 684 & 909 & 648 & 2376 \\
\hline $0.24-0.36$ & Dense Veg. & 324 & 306 & 243 & 1062 \\
\hline \hline
\end{tabular}

Table 6

Change in Build-up Area from the Year 2005 to 2020

\begin{tabular}{cccccc}
\hline \hline \multirow{2}{*}{$\begin{array}{c}\text { NDBI Value } \\
\text { Range }\end{array}$} & Land use & \multicolumn{2}{c}{$\begin{array}{c}\text { Area }\left(\mathrm{km}^{2}\right) \\
\text { Ward 23 }\end{array}$} & \multicolumn{2}{c}{$\begin{array}{c}\text { Area }\left(\mathrm{km}^{2}\right) \\
\text { Ward 29 }\end{array}$} \\
\cline { 3 - 6 } & $\mathbf{2 0 0 5}$ & $\mathbf{2 0 2 0}$ & $\mathbf{2 0 0 5}$ & $\mathbf{2 0 2 0}$ \\
\hline$-0.293--0.098$ & Good veg. & 306 & 297 & 324 & 315 \\
\hline$-0.098--0.047$ & Shrubs & 657 & 1008 & 873 & 738 \\
\hline$-0.047--0.012$ & $\begin{array}{c}\text { Bare } \\
\text { Land }\end{array}$ & 1494 & 1647 & 1755 & 1368 \\
\hline$-0.012-0.19$ & $\begin{array}{c}\text { Paved } \\
\text { Surface }\end{array}$ & 1647 & 1431 & 2205 & 2448 \\
\hline $0.19-0.268$ & $\begin{array}{c}\text { Buildup } \\
\text { Area }\end{array}$ & 1116 & 837 & 1647 & 1935 \\
\hline \hline
\end{tabular}

\section{ii. Temporal Change in Building Areas}

Changes in buildup areas represented in Figure 4 from the year 2005 to 2020 of KCC ward 23 and 29 indirectly 
playing a role as an ecosystem service component. In ward 29, the paved surface and build-up areas have been increased by transforming the vegetation land and bare land but most of the buildings are modern residential buildings with rooftop gardening. The study area symbolizes the ancient settlement in the whole Khulna region near the river bank and most of the buildings are old-fashioned, reused for other purposes like schools, madrasas are often covered or beautified with vegetation and the new buildings are densely adorned with vegetation (Field observation). For this reason, the result of ward 23 was somehow distorted and it is false fully showing the increased amount of Bare Land and Shrubs and decrease amount of Metaled Land and Buildup Area whereas ward 29 and ward 23 are one of the most prominent developing commercial areas of Khulna city. So, the increased amount of build areas with vegetation are playing the role of a great ecosystem service component as a whole.
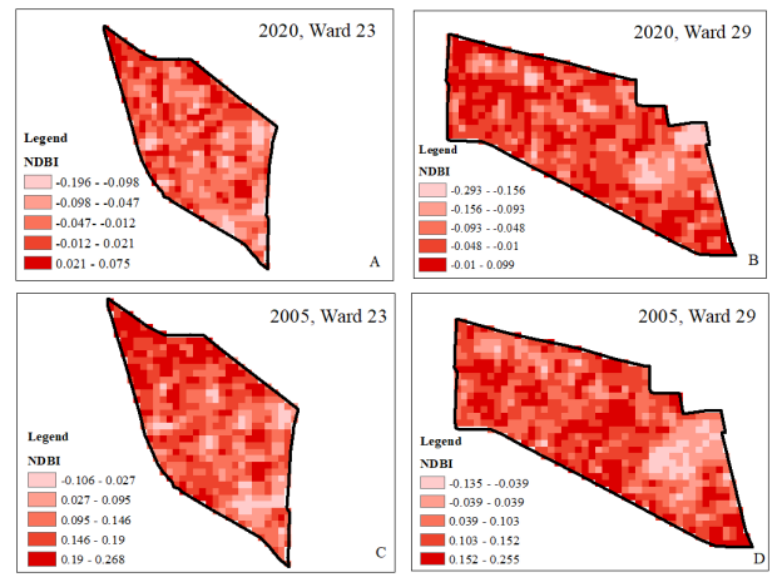

Figure 4: Normalized Difference Build-up Index, (A) 2020, ward 23; (B) 2020, ward 29; (C) 2005, ward 23; and

(D) 2005, ward 29

Assessment of the component of four category indicators present in our study area and their importance discussed in the following points:

\section{iii. Provisioning Service Indicators}

Food, water body and water supply point and ornament species, these three are present in our area of the six indicators. Edible plants in both rooftop gardens and ground gardens, and animals from 2 poultry farms, fish storage farms serve food. The 50 water bodies in the area with an average depth of 7-8 ft. Minimum 4-5 ft. is enough for healthy aquaculture (Staff, 2018). These water bodies holding a rich aquaculture of them maximums are leased and private-owned, both of which are used for fisheries purpose. Ground water through road side community tube well and private electric motor means of water supply. Ornament species often use for beautification of every residences and institutions is like a characteristic of the area.

\section{iv. Habitat or Supporting Indicators}

Nursery is the only supporting service component present in the area. There are two big nurseries that cultivate and conserves different local species of flower, fruit and other

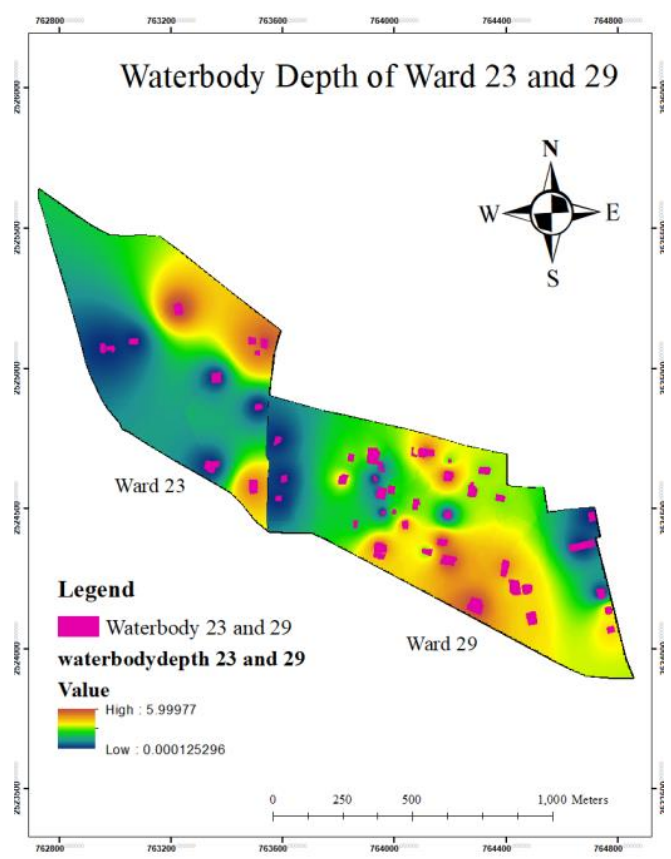

Figure 5: Waterbody depth

ornament species for commercial purpose or for scientific experiment for production of the healthy and superior plant, preservation of rare species and conserve the biodiversity (Field observation) which enriching the ecosystem of the area.

\section{iv. Regulating Service Indicators}

Agricultural land, greeneries, erosion protection of the water bodies and water regulation are present as regulating service indicator. Under the ownership of the Christian missionary, most of the agricultural and vacant land

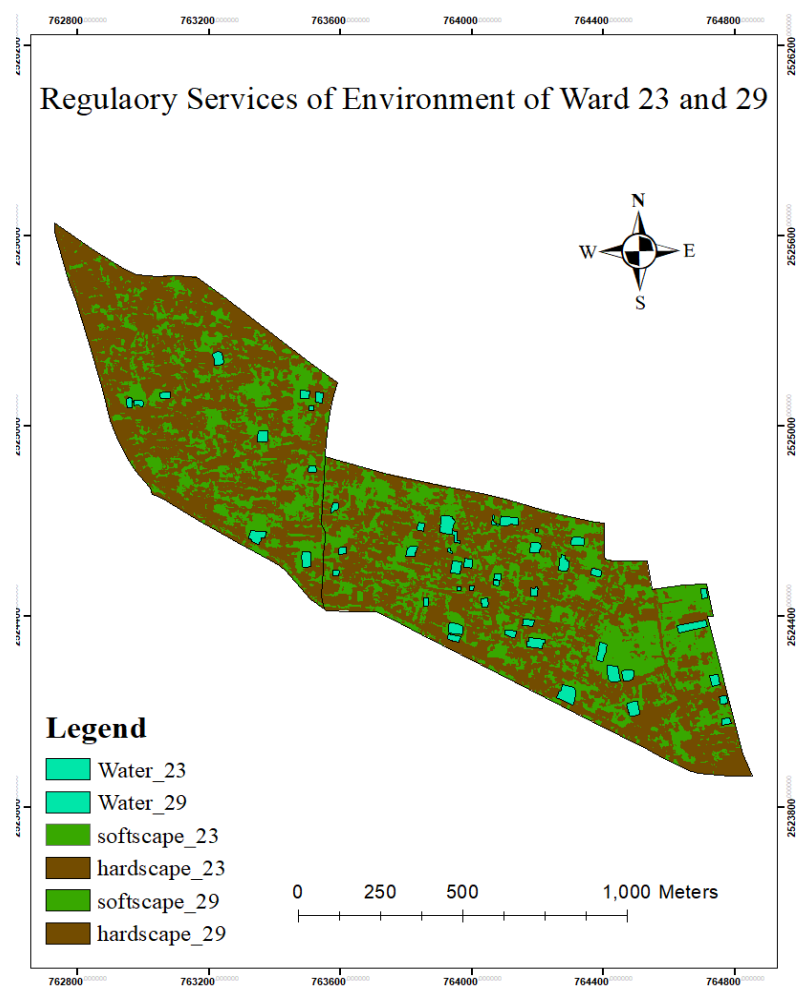

Figure 6: Regulatory services: Land use 
cultivates vegetables, fruits, ornament species, herbal species and trees produce wood in both wards serving the people in many ways and holding a rich biodiversity culture trend. Other private vacant land in front of residential building and agricultural land use for gardening and cultivate vegetable or native fruits, shrubs and ornament species. There are four categories of greeneries based on height in our area such as 1. Big trees like mango, coconut, palm and herbal trees; 2. Medium height trees of fruits and flowers 3. Shrubs like flowers, ornament and darnel species. Except 3 water body 47 are embanked by soil and others are embanked by concrete. The soil type of the area is fine graded that tend to erode. Naturally developed grass and different big and medium height trees planted to prevent erosion of the earthen embankment. These water body are playing a vital role of regulating the water circulation and draining the storm water in the area. The old developed drainage condition of the area is very miserable. Blocked and broken drains are all full of waste and water cannot be drained out effectively through drains and resulted quick water logging and pollution. The amount of annual precipitation is $1736 \mathrm{~mm}$ which is quite high but for the water bodies in the area water logging do stay more than one day even if in heavy rainfall condition. Regulating indicator presented in the study area serving a good environment effectively.

\section{v. Cultural \& Amenities Service Indicators}

Cultural and amenities indicators of the area are 1. Cultural heritage and identity in the sense of place and belongings, 2. Spiritual and religious inspiration, 3. Education and science opportunities and training, 4. Dustbins 5. Amenities. Study area have the ancient settlement near the

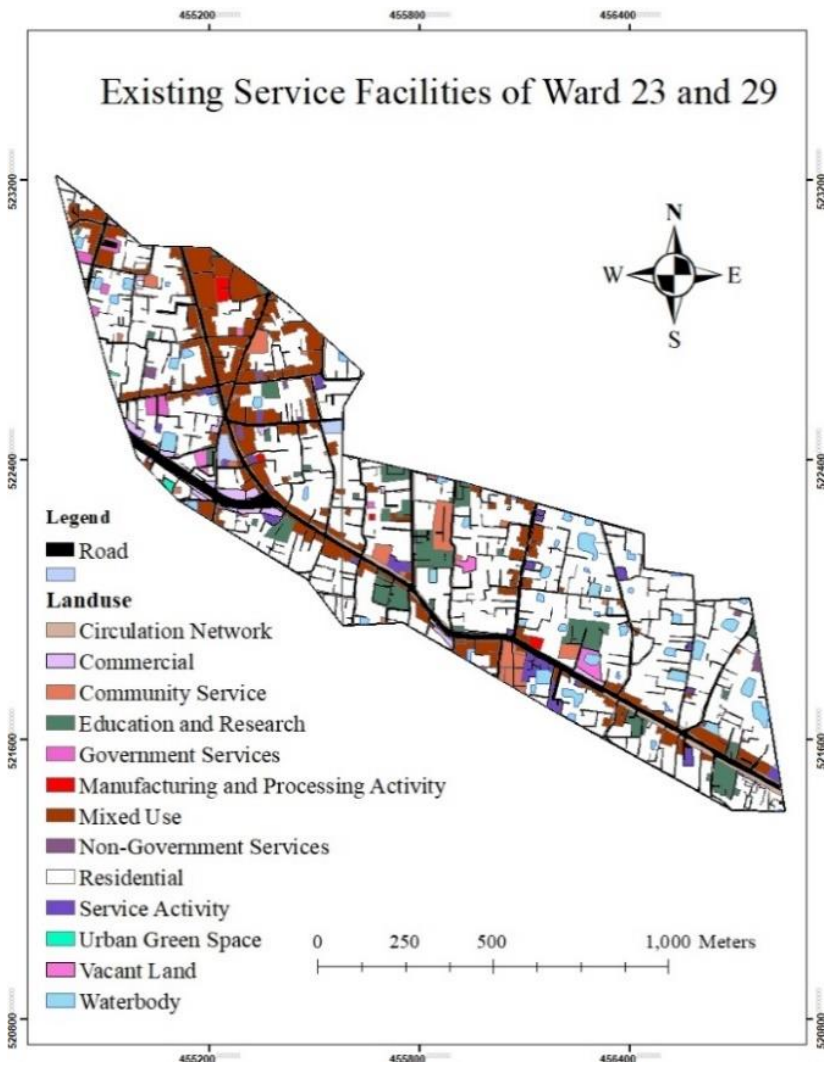

Figure 7: Service facility distribution
Rupsha river symbolizing the traditional Bengali architecture on building patterns and designs of old residential and religious buildings, educational and administrative institutions and restaurants are now playing the role as a sense of heritage and identity for the present generation. Presently the buildings have no warrior or public building are converted the use such as the old office of the General Deputy Postmaster of Khulna division converting to the museum, some residence like "White House" in ward 23 converted to a restaurant. Many mosques, two Hindu temples and one Church and graveyard of Christian serve as the religious and spiritual inspiration to the people of the study area. There are many schools, two colleges and one orphanage as an educational center in the area. Local Government Engineering Department is an experiment center that experiments with construction materials, road circulation and handles local level physical development. "Karitash" operated by Christian Missionaries and "BRAC" these two NGOs provide technical and skill development training and "AVA Center" serves as the training center of the people of the area. The area has all necessary urban amenities and utilities and dustbins for collection.

\section{Ecosystem Dis-service Components}

The study area has different disservice component that is not convenient, risky and hazardous in some cases. The following disservices are present in our study area:

\section{i. Open Waste Dumping Points}

There are only three waste dumping points in which a few amounts of people, are insufficient for gathering the waste generated by the people of the area. Moreover, the dustbins are open, Privatization of waste management systems,

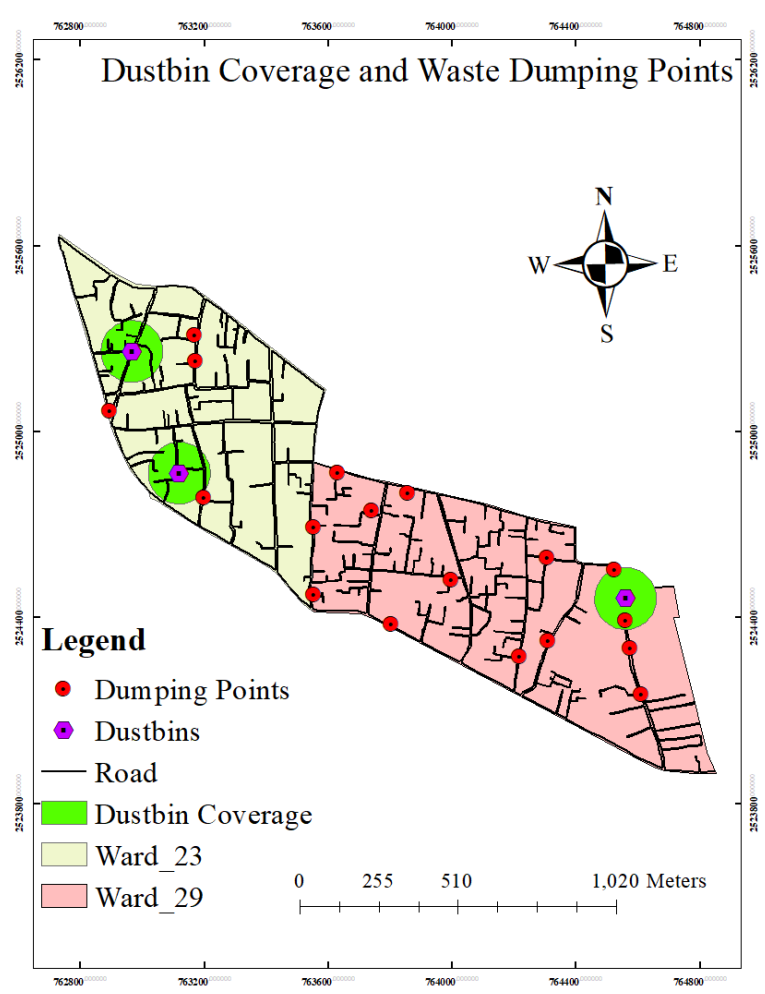

Figure 8: Maps showing waste dumping points and their range with pictures of those areas 
irregularity of waste collection, just one-time waste collection per day and insufficiency of dustbins people throw waste in road sides, drains, water bodies and open spaces that so much unhealthy and in case of unmanaged clinical waste it is hazardous for the people of the area. Identification of the location of all the open waste dumping points have been done and 4 of them are beside the hospital and the clinical waste was kept open and scattered. In this pandemic situation this can cause severe health hazard for the people.

\section{ii. Sediment Export on Water Body and Water Quality Degradation}

Sediment export on some water bodies resulted from land filling, silt comes from water runoff and nearby contractions reduce the depth of the water body, toxic chemical contamination and degrades the water quality which is unhealthy for the aquaculture in some cases and posed threat to the ecosystem in the water body. Different types of water hyacinths, darnel species and waste in the surface of the water body (Location: 763928.16mE, $2524686.99 \mathrm{mN}$ Figure 9(A) and $764065.21 \mathrm{mE}$, $2524692.17 \mathrm{mN}$ Figure 9(B) also degrades the water quality which can destroy the function of the water body and the ecosystem in it.

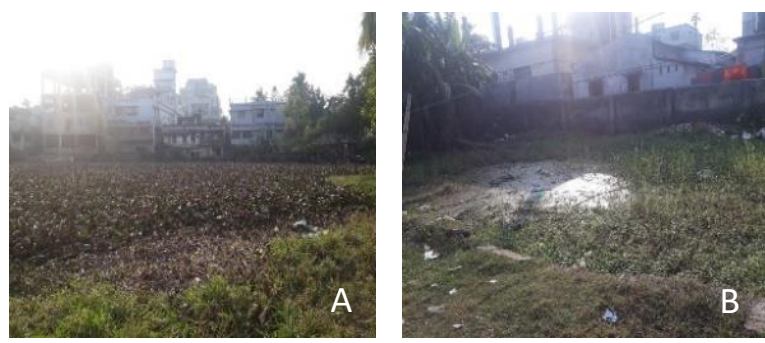

Figure 9: Water quality degradation on two areas A and B of the existing area

\section{iii. Poor Drainage System}

Open, blocked with a waste, broken slab of close drain resulted from poor construction method, damage of construction material for ending of the lifecycle of the construction material, poor maintenance, poor service capacity and abuse of the drains. The impact of the poor drainage system is waterlogging, insects bore for blockage, insect-borne diseases in the summer and winter (No water runoff happen then) season can cause a health hazard and mainly the drains are not functioning well. The area being low lying also posed negative effects.

\section{iv. Violation of Rule and Risk of Collapse and Debris}

Under the "Bangladesh Water Act 2013" Article S20 and S21states that structure is not allowed to be constructed above or in the embankment of the water body which would changes the water flow and deteriorated the water quality. But the office of the ward 29 is situated above a water body and a mosque is constructed close to embankment. Waste generated from the office and adjacent mosque continuously deteriorating the water quality. The slab of the drain which is mainly used for footpath are often broken. Old damaged residential building are still used by people which is very risky, can cause severe accident like death due to the collapse of the structures. The map in Figure 11 shows the risky old building which is still used for different purposes which were about four in number. The area being an old area the presence of old buildings was a unique characteristic of the region and the Figure $10(a, b, c)$ shows some pictures of the risky buildings and structures on the survey region.
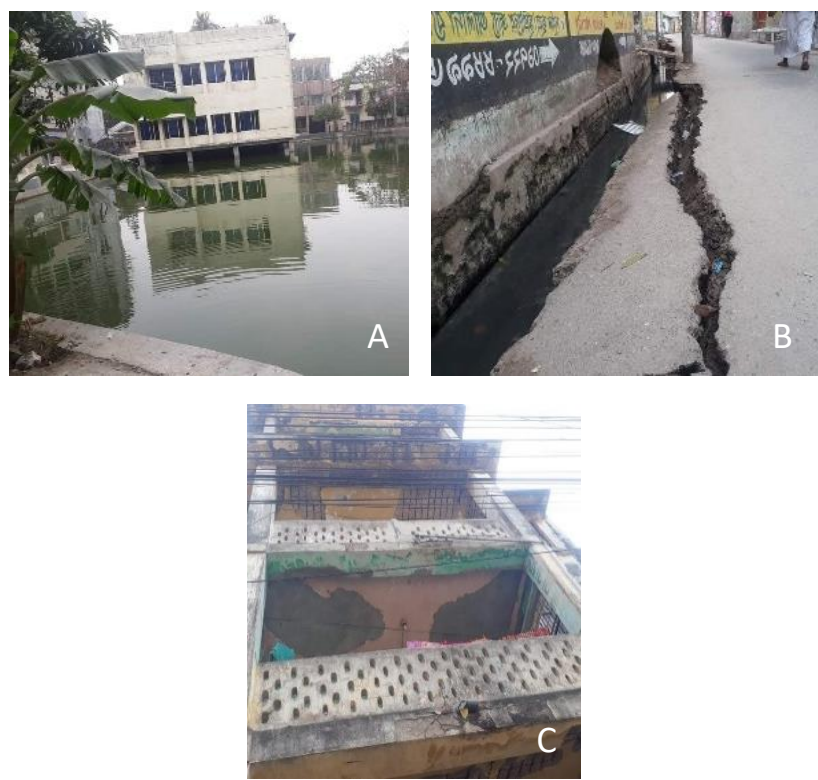

Figure 10: Violation of Rule and Risk of Collapse and Debris

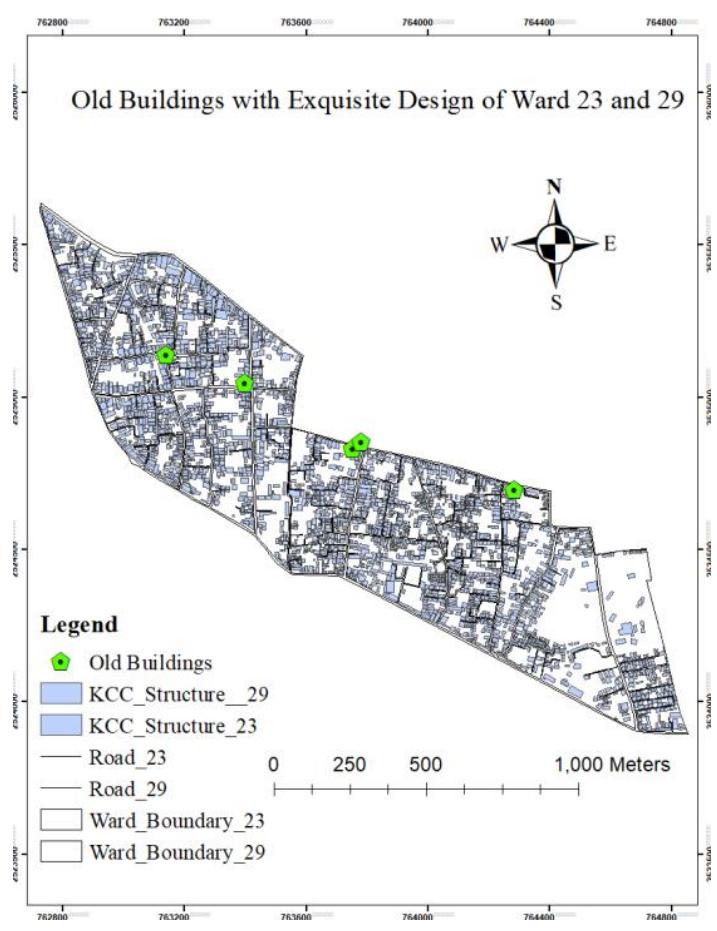

Figure 11: Risk prone old building location

\section{CONCLUSIONS}

The vegetation coverage of the area has shown satisfactory result over the year and indicates that improvement of a diverse and enriched ecosystem through increased vegetation, cultivation and gardening practices. With increase of buildup area, the rooftop gardening practice also indirectly balancing the impact of reduction of the 
vegetation land in the ecosystem. The environmental service components have positioned the environment of the study area at a satisfactory level which ultimately is a positive sign for the urban environment and also balance the ecosystem as well. But the disservice element of the study area like open waste dumping points and drains, risk of collapsed and debris, sedimentation and water quality degradation, violation of rule are very inconvenient for people, environment and ecosystem of the study area. In some cases, it might pose a threat to people and street animals as well. The study addressed the change in environmental condition of the area over the years through imagery analysis but certain scopes were yet to be touched where blue ecosystem condition could have been analyzed. Also, in depth field data were not been able to be collected due to COVID-19 pandemic. So, the research is open for further investigation and analysis of both land and water ecosystem services sorting out the disservices and finding solutions for better overall environment condition.

\section{ACKNOWLEDGEMENTS}

Authors would like to express their gratitude to the Department of Urban and Regional Planning, Khulna University of Engineering \& Technology, Khulna-9203, Bangladesh. The authors also would like to thank the Editors and anonymous reviewers of the the MIJST for their insightful comments to improve the contents of the article.

\section{REFERENCES}

Alam, S., \& Mohammad, S. N. (2018). Applying the ecosystem approach to the Sundarbans of Bangladesh: Possibilities and challenges. Review of European, Comparative and International Environmental Law, 27(2), 115-129. https://doi.org/10.1111/reel.12230

Aldana-Domínguez, J., Montes, C., Martínez, M., Medina, N., Hahn, J., \& Duque, M. (2017). Biodiversity and Ecosystem Services Knowledge in the Colombian Caribbean: Progress and Challenges. Tropical Conservation Science, 10, 1-41. https://doi.org/10.1177/1940082917714229

Andersson, E., Barthel, S., \& Ahrné, K. (2007). Measuring socialecological dynamics behind the generation of ecosystem services. Ecological Applications, 17(5), 1267-1278. https://doi.org/10.1890/06-1116.1

Bolund, P., \& Hunhammar, S. (1999). Ecosystem services in urban area. Ecological Economics, 29(2), 293-301. https://doi.org/10.1017/S174217051300046X

Chabay, I. (2018). Land degradation and restoration. In Companion to Environmental Studies. https://doi.org/10.4324/9781315640051-105

de Groot, R. S., Alkemade, R., Braat, L., Hein, L., \& Willemen, L. (2010). Challenges in integrating the concept of ecosystem services and values in landscape planning, management and decision making. Ecological Complexity, 7(3), 260-272. https://doi.org/10.1016/j.ecocom.2009.10.006

European Environment Agency. (2011). Green infrastructure and territorial cohesion. In Tecnical Report (Number 18) (Issue 18).

Gómez-Baggethun, E., \& Barton, D. N. (2013). Classifying and valuing ecosystem services for urban planning. Ecological Economics, 86(February) https://doi.org/10.1016/j.ecolecon.2012.08.019
Hanna, D. E. L., Tomscha, S. A., Ouellet Dallaire, C., \& Bennett, E. M. (2018). A review of riverine ecosystem service quantification: Research gaps and recommendations. Journal of Applied Ecology, 55(3), 1299-1311. https://doi.org/10.1111/1365-2664.13045

Haque, M. N., Morshed, S. R., Fattah, M. A., Ishra, A. K., \& Saroar, M. (2020). Environmental Risk Zone Identification of an Urban Unit Using GIS and Remote Sensing. BAUET JOURNAL, 2(2), 25-39.

Isbell, F., Gonzalez, A., Loreau, M., Cowles, J., Díaz, S., Hector, A., MacE, G. M., Wardle, D. A., O'Connor, M. I., Duffy, J. E., Turnbull, L. A., Thompson, P. L., \& Larigauderie, A. (2017). Linking the influence and dependence of people on biodiversity across scales. Nature, 546(June), 65-72. https://doi.org/10.1038/nature22899

Islam, M. M., Sunny, A. R., Hossain, M. M., \& Friess, D. A. (2018). Drivers of mangrove ecosystem service change in the Sundarbans of Bangladesh. Singapore Journal of Tropical Geography, 39(2), 244-265. https://doi.org/10.1111/sjtg.12241

Le Saout, S., Hoffmann, M., Shi, Y., Hughes, A., Bernard, C., Brooks, T. M., Bertzky, B., Butchart, S. H. M., Stuart, S. N., Badman, T., \& Rodrigues, A. S. L. (2013). Protected areas and effective biodiversity conservation. Science, 342(6160), 803-805. https://doi.org/10.1126/science.1239268

Lyytimäki, J., Petersen, L. K., Normander, B., \& Bezák, P. (2008). Nature as a nuisance? Ecosystem services and disservices to urban lifestyle. Environmental Sciences, 5(3), 161-172. https://doi.org/10.1080/15693430802055524

Maskell, L. C., Crowe, A., Dunbar, M. J., Emmett, B., Henrys, P., Keith, A. M., Norton, L. R., Scholefield, P., Clark, D. B., Simpson, I. C., \& Smart, S. M. (2013). Exploring the ecological constraints to multiple ecosystem service delivery and biodiversity. Journal of Applied Ecology, 50(3), 561-571. https://doi.org/10.1111/1365-2664.12085

Odum, E. P. (1989). Ecology and our endangered life-support systems. Environmental Entomology, 20(1), 283. https://doi.org/10.2307/1352581

Rabbi, M. F., Sami, F. Y., Rimi, A. A., \& Haque, M. N. (2021). Environmental profiling of an urban unit. In Imam, Rahman, \& Pal (Eds.), Proceedings of the 5th International Conference on Advances in Civil Engineering (ICACE 2020) (Issue May, pp. 65-72).

Rasmussen, L. V., Christensen, A. E., Danielsen, F., Dawson, N., Martin, A., Mertz, O., Sikor, T., Thongmanivong, S., \& Xaydongvanh, P. (2017). From food to pest: Conversion factors determine switches between ecosystem services and disservices. Ambio, 46(2), 173-183. https://doi.org/10.1007/s13280-016-0813-6

Rendón, O. R., Garbutt, A., Skov, M., Möller, I., Alexander, M., Ballinger, R., Wyles, K., Smith, G., McKinley, E., Griffin, J., Thomas, M., Davidson, K., Pagès, J. F., Read, S., \& Beaumont, N. (2019). A framework linking ecosystem services and human well-being: Saltmarsh as a case study. People and Nature, 1(4), 486-496. https://doi.org/10.1002/pan3.10050

Rokonuzzaman, M., \& Rahman, M. M. (2017). Effect of Cloud Coverage on Sunshine, Humidity, Rainfall and Temperature for Different Weather Stations in Bangladesh: A PanelAnalysis. IOSR Journal of Environmental Science, Toxicology and Food Technology, 11(03), 01-06. https://doi.org/10.9790/2402-1103010106

Sannier, C., McRoberts, R. E., Fichet, L. V., \& Makaga, E. M. K. (2014). Using the regression estimator with landsat data to estimate proportion forest cover and net proportion deforestation in gabon. Remote Sensing of Environment, 
151(August), 138-148. https://doi.org/10.1016/j.rse.2013.09.015

Sarker, S. K., Reeve, R., Paul, N. K., \& Matthiopoulos, J. (2019). Modelling spatial biodiversity in the world's largest mangrove ecosystem-The Bangladesh Sundarbans: A baseline for conservation. Diversity and Distributions, 25(5), 729-742. https://doi.org/10.1111/ddi.12887

Schaubroeck, T. (2017). A need for equal consideration of ecosystem disservices and services when valuing nature; countering arguments against disservices. Ecosystem Services, 26(August),

95-97. https://doi.org/10.1016/j.ecoser.2017.06.009

Shackleton, C. M., Ruwanza, S., Sinasson Sanni, G. K., Bennett, S., De Lacy, P., Modipa, R., Mtati, N., Sachikonye, M., \& Thondhlana, G. (2016). Unpacking Pandora's Box: Understanding and Categorising Ecosystem Disservices for Environmental Management and Human Wellbeing. Ecosystems, 19(4), 587-600. https://doi.org/10.1007/s10021015-9952-z

Singh, A. (1989). Review Articlel: Digital change detection techniques using remotely-sensed data. International Journal of Remote Sensing, 10(6), 989-1003. https://doi.org/10.1080/01431168908903939
Smart, J. C. R., Hicks, K., Morrissey, T., Heinemeyer, A., Sutton, M. A., \& Ashmore, M. (2011). Applying the ecosystem service concept to air quality management in the UK: A case study for ammonia. Environmetrics, 22(5), 649-661. https://doi.org/10.1002/env.1094

Staff, K. (2018). Dimensions : Dig DIFFERENT Sized Fish Ponds. https://krishijagran.com/news/dimensions-dig-different-sizedfish-ponds

Sun, Y., Hao, R., Qiao, J., \& Xue, H. (2020). Function zoning and spatial management of small watersheds based on ecosystem disservice bundles. Journal of Cleaner Production, 255(May), 1-10. https://doi.org/10.1016/j.jclepro.2020.120285

Tian, Y., Wu, H., Zhang, G., Wang, L., Zheng, D., \& Li, S. (2020). Perceptions of ecosystem services, disservices and willingness-to-pay for urban green space conservation. Journal of Environmental Management, 260(110140), 1-12. https://doi.org/10.1016/j.jenvman.2020.110140

Tzoulas, K., Korpela, K., Venn, S., Yli-Pelkonen, V., Kaźmierczak, A., Niemela, J., \& James, P. (2007). Promoting ecosystem and human health in urban areas using Green Infrastructure: A literature review. Landscape and Urban Planning, $\quad 81(3)$, https://doi.org/10.1016/j.landurbplan.2007.02.001 